\title{
FAKTOR-FAKTOR YANG BERHUBUNGAN DENGAN KEJADIAN BBLR DI RUANG BERSALIN RUMAH SAKIT UMUM SEKOTA KENDARI
}

\author{
Relating To The Incidence Of Lbw In The Delivery Room Of The Kendari City General \\ Hospital
}

\author{
Ulfa Ultriani ${ }^{1}$ Timbul Supodo $^{2}$ La Ode Kamalia $^{3}$ \\ ${ }^{1}$ Mahasiswa Program Studi Magister Kesehatan Masyarakat \\ Sekolah Tinggi Ilmu Kesehatan Mandala Waluya Kendari \\ Email: ultrianiulfa@gmail.com
}

\begin{abstract}
ABSTRAK
Berdasarkan data dari program Kesehatan Ibu \& Anak (KIA) Kabupaten atau Kota tahun 2018 di Provinsi Sulawesi Tenggara, jumlah kematian neonatal adalah 257 kasus dengan penyebab kematian diantaranya BBLR, asfiksia, kelahiran congenital, sepsis, ikterus dan lain-lain. Tujuan penelitian ini adalah untuk menganalisis faktor-faktor yang berhubungan dengan kejadian BBLR di ruang bersalin Rumah Sakit Umum Sekota Kendari. Penelitian dilakukan adalah penelitian kuantitatif dengan rancangan case control study.Populasi dalam penelitian ini adalah seluruh bayi yang lahir di ruang bersalin Rumah Sakit sekota Kendari pada tahun 2018 yang berjumlah 1.021 bayi.Jumlah sampel pada penelitian ini adalah 88 orang terbagi dua yakni 44 orang kelompok kasus dan 44 orang untuk kelompok kontrol. Penentuan sampel dilakukan dengan teknik simpel random sampling. Data diolah menggunakan uji chi square dan odds ratio. Hasil uji chi square menunjukkan bahwa anemia berhubungan dengan kejadian BBLR (pvalue $=0,001$, $\mathrm{OR}=4,610$ ). Status gizi berhubungan dengan kejadian BBLR (pvalue =0,000, OR=6,359). Pelayanan antenatal berhubungan dengan kejadian BBLR (pvalue $=0,003, \mathrm{OR}=4,173$ ). Adapun kesimpulan dalam penelitian ini adalah ada hubungananemia, status gizi, umur ibu, pendapatan keluarga dan pelayanan antenatal dengan kejadian berat badan lahir rendah. Adapun yang menjadi saran dalam penelitian ini adalah Dinas Kesehatan diharapkan membuat kebijakan dan menerapkan kebijakan tentang program usia sehat untuk melahirkan anak dalam rangka pencegahan terhadap faktor risiko melahirkan bayi dengan BBLR.
\end{abstract}

Kata Kunci : Berat Badan Lahir Rendah, Anemia, Status Gizi.

\section{ABSTRACT}

Based on data from the District or City 2018 Maternal \& Child Health (MCH) program in Southeast Sulawesi Province, the number of neonatal deaths is 257 cases with causes of death including $L B W$, asphyxia, congenital births, sepsis, jaundice and others. The purpose of this study was to analyze the factors associated with the incidence of $L B W$ in the delivery room of the Kendari City General Hospital. The study was a quantitative study using a case control study design. The population in this study were all babies born in the delivery room of the hospital in the city of Kendari in 2018, amounting to 1,021 babies. The number of samples in this study were 88 people divided into two, namely 44 case groups and 44 people for the control group. Determination of the sample is done by simple random sampling technique. Data were processed using chi square test and odds ratio. Chi square test results showed that anemia was associated with LBW events ( $p$ value $=0.001, O R=4,610$ ). Nutritional status is related to LBW incidence ( $p$ value $=0,000, O R=6.359)$. Maternal age is associated with LBW events $(p$ value $=0.001$, OR $=5.110)$. Family income is related to LBW events ( $p$ value $=0.008, O R=3.728$ ). Antenatal care is associated with $L B W$ events $(p$ value $=0.003, O R=4.173)$. The conclusion in this study is that there is an association of anemia, nutritional status, maternal age, family income and antenatal care with the incidence of low birth weight. As for the suggestions in this study is the Health Department is expected to make policies and implement policies regarding the healthy age program to give birth to children in order to prevent the risk factors for giving birth to babies with $\mathrm{LBW}$.

Keywords: Low Birth Weight, Anemia, Nutritional Status. 


\section{PENDAHULUAN}

Bayi dengan berat badan lahir rendah (BBLR) masih menjadi masalah di dunia, karena penyebab timbulnya penyakit dan kematian pada bayi yang baru lahir (Anik and Nurhayati, 2009). Hal ini terbukti dengan jumlah kasus yang masih cukup tinggi yakni, $15 \%$ dari 20 juta bayi di seluruh dunia lahir dengan BBLR setiap tahunnya (WHO, 2014). Angka kematian bayi merupakan salah satu indikator dalam menentukan derajat kesehatan anak.Periode neonatal (28 hari pertama kehidupan) merupakan waktu yang paling rentan untuk kelangsungan hidup anak. Tahun 2013 hampir satu juta bayi baru lahir meninggal pada 24 jam petama kehidupan, artinya sebesar 16\% dari total kematian Balita dan lebih dari sepertiga dari kematian neonatal(WHO, 2015b).

Bayi dengan Berat Badan Lahir Rendah (BBLR) dianggap sebagai penyebab utama kematian bayi terutama pada bulan pertama kehidupan. Secara global, $40-60 \%$ dari kematian bayi di dunia disebabkan oleh BBLR (UNICEF, 2015). Angka kematian pada BBLR 35 kali lebih tinggi dibanding dengan bayi dengan berat lahir lebih dari 2500 gram (Pantiawati, 2010). BBLR merupakan penyebab kematian perinatal tertinggi ke dua di Indonesia setelah Intra Uterin Fetal Death (IUFD) yaitu sebesar 11,2\% (Kemenkes RI, 2015).

Kejadian BBLR tercatat yakni di Asia Tengah yakni $(27,1 \%)$ dan di Eropa $(6,4 \%)$. Asia Tenggara memiliki insidensi BBLR paling tinggi yaitu $27 \%$ dari seluruh kelahiran bayi BBLR di dunia. Tahun 2010, angka kejadian BBLR di Indonesia sebesar $11,1 \%$ masih diatas angka rata-rata Thailand $(6,6 \%)$ dan Vietnam (5,3\%) (WHO, 2015a).

Bayi dengan Berat Badan Lahir Rendah (BBLR) berisiko 20 kali lebih besar meninggal selama masa pertumbuhan jika dibandingkan dengan bayi dengan berat badan lahir normal.Angka kematian bayi meningkat seiring dengan peningkatan insiden BBLR di suatu negara. Berdasarkan data Riskesdas tahun 2013, prevalensi BBLR di Indonesia masih terdapat 10,2\% dan pada tahun 2010 yaitu sebesar $11,1 \%$. Hal ini menunjukkan bahwa presentase bayi dengan berat badan lahir rendah (BBLR) ini menurun landai akan tetapi masih menjadi kebijakan pemerintah sebagai program evaluasi oleh Kemenkes RI (Kemenkes RI, 2013).

Menurut Sarwono (2005) menyatakan bahwa masalah BBLR pada dasarnya berhubungan dengan banyak faktor, diantaranya: 1 . faktor ibu: riwayat kelahiran prematur, perdarahan antepartum, kurangnya nutrisi pada masa kehamilan ibu, hidramnion, penyakit kronik, hipertensi, umur ibu kurang dari 20 tahun atau lebih dari 35 tahun, jarak dua kehamilan terlalu dekat, infeksi, trauma dan paritas 2. faktor janin : cacat bawaan, kehamilan ganda, hidramnion, KPD. Selain itu, keadaan sosial ekonomi yang kurang dari upah minimum regional (UMR) Rp.2.551.463 dan kebiasaan (pekerjaan yang melelahkan dan merokok) juga merupakan faktor yang menyebabkan BBLR.
Sedangkan menurut England (2014) faktor yang paling berperan terjadinya BBLR adalah faktor ibu, faktor janin dan faktor plasenta. Dari tiga faktor tersebut, faktor ibu merupakan yang paling mudah diidentifikasi. Faktor ibu yang berhubungan dengan BBLR antara lain umur ibu ( $<20$ atau $>35$ tahun), jarak kelahiran, status gizi ibu, riwayat BBLR sebelumnya, adanya penyakit kronis (anemia, hipertensi, diabetes melitus) dan faktor sosial ekonomi (sosial ekonomi rendah, pekerjaan fisik yang berat, kurangnya pemeriksaan antenatal, kehamilan yang tidak dikehendaki), serta faktor lain (ibu perokok, pecandu narkoba, dan alkohol) (Proverawati and Ismawati, 2010). Namun faktor yang ada pada suatu daerah yang satu dengan yang lain berbeda, tergantung pada faktor geografis, sosial ekonomi, dan budaya (Bendhari and Haralkar, 2015).

Bayi lahir dengan berat bayi lahir rendah menjadi salah satu faktor resiko yang mempunyai kontribusi terhadap kematian bayi khususnya pada masa perinatal dan hal tersebut akan meningkat sebesar 3.4 kali jika dibandingkan dengan bayi yang lahir dengan berat yang normal (Aliyu et al 2012). Penyebab BBLR secara umum bersifat multifaktorial, namun menurut Hollingworth (2008) penyebab BBLR dipengaruhi oleh dua faktor yaitu faktor internal dan eksternal.Faktor internal terdiri atas faktor ibu, janin, dan uterus plasenta.Faktor eksternal terdiri atas faktor sosial dan lingkungan. Faktor ibu terdiri atas karakteristik ibu (usia, paritas, jarak kehamilan, lingkar lengan atas (LILA), tinggi badan, dan status gizi) dan faktor pendukung lainnya yaitu (usia kehamilan, pertambahan berat badan, ante natal care (ANC), hemoglobin, suplementasi Fe, dan tekanan darah). Menurut Smeltzer et al (2002) kejadian BBLR disebabkan oleh anemia, dan ukuran LILA ibu $<23.5 \mathrm{~cm}$.

Berdasarkan data dari program Kesehatan Ibu \& Anak (KIA) Kabupaten atau Kota tahun 2018 di Provinsi Sulawesi Tenggara, jumlah kematian neonatal adalah 257 kasus dengan penyebab kematian diantaranya BBLR, asfiksia, kelahiran congenital, sepsis, ikterus dan lain-lain (Dinkes Provinsi Sultra, 2018).

Data dari Profil Kesehatan Provinsi Sulawesi Tenggara tahun 2018 didapatkan bahwa kejadian BBLR berdasarkan kategori tertinggi hingga terendah di Kabupaten atau Kota yakni, 
tertinggi di Kabupaten Konawe sebanyak 151 kasus (3,22\%), Kabupaten Kolaka 149 kasus $(3,39 \%)$, Kota Kendari sebanyak 148 kasus $(1,48 \%)$, Kabupaten Konawe Selatan 142 kasus (2,53\%), Kabupaten Bombana sebanyak 74 kasus $(2,02 \%)$, Kabupaten Wakatobi 64 kasus $(3,45 \%)$, Kota Bau-Bau 59 kasus $(2,10 \%)$, Kabupaten Konawe Utara 17 kasus $(1,32 \%)$, Kabupaten Muna 14 kasus $(0,36 \%)$, dan terendah di Kabupaten Muna Barat sebanyak 5 kasus $(0,35 \%)$ dan secara keseluruhan jumlah BBLR di Provinsi Sulawesi Tenggara sebanyak 1.107 kasus (2,29\%) (Dinkes Provinsi Sultra, 2018).

Studi pendahuluan yang dilakukan diketahui bahwa faktor yang dapat diduga sebagai penyebab BBLR adalah anemia, status gizi, pendapatan keluarga, serta pelayanan antenatal. Hal tersebut diperkuat saat melakukan wawancara awal kepada $10 \mathrm{ibu}$ di RSU Bahteramas Provinsi Sultra bahwa 4 orang ibu memiliki riwayat anemia, $3 \mathrm{ibu}$ dengan status gizi kurang berdasarkan dari pengukuran berat badan dan tinggi badan serta ukuran LILA, 3 ibu mengatakan bahwa tidak lengkap dalam melakukan pemeriksaan antenatal serta kemampuan keluarga dalam menyediakan makanan yang bergizi bagi ibu saat hamil sangat terbatas karena terbentur dengan keperluan lain di rumah tangga. Tujuan penelitian ini adalah untuk menganalisis faktor-faktor yang berhubungan dengan kejadian BBLR di ruang bersalin Rumah Sakit Umum Sekota Kendari.

\section{METODE}

Penelitian ini menggunakan metode penelitiankuantitatif dengan menggunakan rancangan case control study(Sugiyono, 2011)Penelitian ini telah di laksanakan mulai tanggal 5 Juli sampai dengan 23 Agustus 2019. Populasi dalam penelitian ini adalah seluruh bayi yang lahir di ruang bersalin Rumah Sakit sekota Kendari pada tahun 2018 yang berjumlah 1.021 bayi. Sedangkan sampel berjumlah 44 orang untuk kelompok kasus dan 44 orang untuk kelompok kontrol. Penentuan sampel dengan menggunakan teknik simple random sampling.

Analisis data penelitian menggunakan analisis deskriptif dan analisis inferensial.Adapun rumusan dalam analisis deskriptif yaitu:

$\mathrm{x}=\frac{\mathrm{f}}{\mathrm{n}} \mathrm{k}$

Keterangan : $\mathrm{x} \quad$ : Persentase hasil yang diteliti

f : variable yang di teliti/frekuensi skor jawaban yang benar

$\mathrm{n}$ : Jumlah sampel

k : Konstanta (100\%)(Sugiyono, 2011).

Analisis inferensial menggunakan uji statistik chi square. Adapun rumus uji Chi-square, yaitu:

$\mathrm{X}^{2}=\sum$ $(\mathrm{O}-\mathrm{E})^{2}$

$\mathrm{E}$

Keterangan:

$\mathrm{X}^{2}=$ Nilai Chi-square.

$\mathrm{O}=$ Frekuensi yang diobservasi.

$\mathrm{E}=$ Frekuensi yang diharapkan

Pengambilan Keputusan :

1) Apabila $X^{2}$ hitung $>X_{\text {tabel }}^{2}$, maka Ho ditolak dan Ha diterima, artinya ada hubungan antara variabel independen dengan variabel dependen.

2) Apabila $X^{2}{ }_{\text {hitung }}<X 2_{\text {tabel }}$, maka Ho diterima dan Ha ditolak, artinya tidak ada hubungan antara variabel independen dengan variabel dependen.

\section{HASIL}

Pengumpulan data dilakukan pada 36 responden dengan hasil sebagai berikut :

Tabel 1.

Distribusi Anemia dan Status Gizi ibu Hamil dengan kejadian BBLR di Ruang Bersalin RSU Sekota Kendari

\begin{tabular}{|c|c|c|c|}
\hline \multirow[t]{2}{*}{ Variabel } & \multicolumn{2}{|c|}{$\begin{array}{c}\text { Kejadian } \\
\text { BBLR }\end{array}$} & \multirow{2}{*}{$\begin{array}{l}\mathrm{T} \\
\text { ot } \\
\text { al }\end{array}$} \\
\hline & $\begin{array}{c}\text { Kas } \\
\text { us }\end{array}$ & $\begin{array}{c}\text { Kont } \\
\text { rol }\end{array}$ & \\
\hline \multicolumn{4}{|l|}{ Anemia } \\
\hline Anemia & 31 & 15 & $\begin{array}{l}4 \\
6\end{array}$ \\
\hline Tidak Anemia & 13 & 29 & $\begin{array}{l}4 \\
2\end{array}$ \\
\hline \multicolumn{4}{|l|}{ Status Gizi } \\
\hline KEK & 31 & 12 & $\begin{array}{l}4 \\
3\end{array}$ \\
\hline Tidak KEK & 13 & 32 & $\begin{array}{l}4 \\
5\end{array}$ \\
\hline
\end{tabular}

Pada tabel 1,menunjukkan bahwa yang anemia berjumlah 46 orang dan tidak anemia 42 orang. Sedangkan responden yang pernah mengalami KEK berumlah 43 orang dan tidak KEK berjumlah 45 orang 


\section{Analisis Inferensial}

Tabel 2.

Analisis Hubungan Anemia dan Status Gizi dengan Kejadian Berat Badan Lahir Rendah di RSU Sekota Kendari

\begin{tabular}{lccc}
\hline Variabel & $\begin{array}{c}\mathbf{X}^{\mathbf{2}} \\
\text { Hitung }\end{array}$ & $\begin{array}{c}\mathbf{P} \\
\text { value }\end{array}$ & OR \\
\hline Anemia & 10,248 & 0,001 & 4,610 \\
Status Gizi & 8,945 & 0,003 & 0,55 \\
\hline
\end{tabular}

Data tabel 2 menunjukkan bahwa, uji Chisquare pada $\alpha=5 \%$ dan $\mathrm{df}=1$, diperoleh nilai uji chi square 10,248 lebih besar dari $\mathrm{X}^{2}$ tabel= 3,841 dan $\mathrm{p}$ value $=0,001$.hal ini berarti hipotesis diterima, artinya bahwa ada hubungan antara anemia dengan kejadian BBLR di Ruang Bersalin Rumah Sakit Umum Sekota Kendari. Hasil analisis dengan menggunakan uji Odds Ratio diperoleh nilai Odds Ratio $(\mathrm{OR})=4,610$, CI 95\% = 1,877-11,327, hal ini berarti ibu yang saat hamil mengalami anemia akan berisiko 4,610 kali lebih besar bayinya mengalami BBLR dibandingkan dengan ibu yang saat hamil tidak mengalami anemia.

Hasil uji statistik dengan menggunakan uji Chisquare pada $\alpha=5 \%$ dan $\mathrm{df}=1$, diperoleh nilai $p$ value $=0,000$ hal ini berarti hipotesis diterima, artinya bahwa ada hubungan antara status Gizi ibu saat hamil dengan kejadian BBLR di Ruang Bersalin Rumah Sakit Umum Sekota Kendari. Hasil analisis dengan menggunakan uji Odds Ratio diperoleh nilai Odds Ratio $(\mathrm{OR})=6,359$, CI 95\% $=2,516-16,071$, hal ini berarti ibu yang saat hamil mengalami KEK akan berisiko 6,359 kali lebih besar bayinya mengalami BBLR dibandingkan dengan ibu yang saat hamil tidak mengalami KEK.

\section{Pembahasan}

\section{Hubungan Anemia dengan Kejadian BBLR}

Anemia lebih sering ditemukan dalam kehamilan karena selama kehamilan keperluan akan zat makanan bertambah dengan adanya perubahan dalam darah dan sumsum tulang. Pertambahan volume darah selama kehamilan disebut dengan hipervolemia. Namun pertambahan volume darah ini lebih sedikit dibandingkan dengan bertambahnya plasma darah sehingga terjadi pengenceran darah (Hanifa 2005). Pengenceran darah digunakan untuk penyesuaian fisiologis dalam kehamilan dan meringankan beban kerja jantung yang harus bekerja lebih berat selama masa kehamilan. Kerja jantung akan menjadi ringan apabila viskositas darah rendah. Resistensi perifer juga berkurang sehingga tekanan darah naik, pada pada perdarahan selama persalinan banyaknya unsur zat besi lebih sedikit hilang dibandingkan apabila darah itu tetap kental (Manuaba 2007). Hemodilusi dimulai pada trimester pertama kehamilan yaitu pada minggu 12-20 dan hemodilusi maksimal terjadi pada umur kehamilan 20-36 minggu. Akibat hemodilusi saja kadar hemoglobin darah ibu dapat menurun sampai $10 \mathrm{~g} \%$. Umumnya kondisi ini karena turunnya cadangan zat besi (Sarimawar 2003).

Hasil penelitian menunjukkan dari 46 responden yang mengalami anemia terdapat 31 responden $(67,4 \%)$ yang mengalami BBLR dan 15responden $(32,6 \%)$ yang tidak mengalami mengalami BBLR. Selanjutnya dari 42 responden yang tidak mengalami anemia terdapat 13 responden $(31,0 \%)$ yang mengalami BBLR dan 29 responden $(69,0 \%)$ yang tidak mengalami BBLR.

Hasil uji statistik dengan menggunakan uji Chisquare pada $\alpha=5 \%$ dan df $=1$, diperoleh nilai $p$ value $=0,001$ hal ini berarti hipotesis diterima, artinya bahwa ada hubungan antara anemia dengan kejadian BBLR di Ruang Bersalin Rumah Sakit Umum Sekota Kendari. Hasil analisis dengan menggunakan uji Odds Ratio diperoleh nilai Odds Ratio $(\mathrm{OR})=4,610$, CI 95\% $=1,877-11,327$, hal ini berarti ibu yang saat hamil mengalami anemia akan berisiko 4,610 kali lebih besar bayinya mengalami BBLR dibandingkan dengan ibu yang saat hamil tidak mengalami anemia. Karena nilai OR $(4,610)>$ 1, maka anemia merupakan faktor risiko kejadian BBLR di Ruang Bersalin Rumah Sakit Umum Sekota Kendari.Penelitian ini sejalan dengan penelitian Hartanti (2008) yang menyatakan ada hubungan antara kadar $\mathrm{Hb}$ ibu hamil dengan kejadian BBLR. Masa ibu hamil adalah masa dimana seseorang wanita memerlukan berbagai unsur gizi yang jauh lebih banyak dari pada yang diperlukan dalam keadaan tidak hamil. Diketahui bahwa janin membutuhkan zat-zat gizi dan hanya ibu yang dapat memberikannya. Dengan demikian makanan ibu hamil harus cukup bergizi agar janin yang dikandungnya memperoleh makanan bergizi cukup, untuk alur terhambatnya pertumbuhan dari aspek gizi ibu.

Penelitian ini didukung oleh Nurfitria (2016) Hasil analisis bivariat menunjukkan bahwa kadar hemoglobin berkaitan dengan berat bayi lahir rendah. Nilai OR menunjukkan bahwa Odds Rasio pada ibu yang hamil dengan kadar $\mathrm{Hb}<11$ gram /dl beresiko melahirkan bayi dengan berat badan rendah 2.635 kali lebih besar dibandingkan dengan ibu hamil dengan kadar $\mathrm{Hb}=11$ gram/dl. Hal tersebut sejalan dengan penelitian Merzalia (2012) yang menyatakan bahwa ibu hamil dengan kadar $<11$ gram/dl beresiko melahirkan BBLR 4.397 kali lebih besar dibandingkan dengan ibu hamil dengan kadar $\mathrm{Hb}=$ $11 \mathrm{gram} / \mathrm{dl}$.

Kategori hemoglobin dibagi menjadi 2 kelompok yaitu anemia $(<11 \mathrm{gr} / \mathrm{dl})$ dan tidak anemia $(>11 \mathrm{~g} / \mathrm{dl})$. 
Lebih dari separuh $(64.6 \%)$ contoh tergolong tidak anemia dan lebih dari $3 / 4$ kelompok tersebut melahirkan bayi normal, sedangkan pada kelompok anemia lebih dari 1/3 melahirkan bayi BBLR.

Hal tersebut sesuai dengan teori yang menyebutkan bahwa status anemia dipengaruhi oleh adanya asupan makanan yang mengandung zat besi (Fe) yang rendah sehingga mengakibatkan kadar $\mathrm{Hb}$ ibu hamil rendah. Hemoglobin merupakan parameter yang paling sering dan paling umum digunakan untuk menetapkan prevalensi anemia

Status hemoglobin dapat diartikan sebagai kadar $\mathrm{Hb}$ seseorang yang diperoleh dari hasil pengukuran dengan metode tertentu dan didasarkan pada standar yang telah ditetapkan, dengan demikian kadar $\mathrm{Hb}$ yang kurang dari normal mengidikasikan anemia. Wanita hamil dan beresiko anemia jika kadar Hbnya $<11 \mathrm{~g} \%$. Ibu yang menderita anemia dapat dicegah dengan cara memperbaiki pola makanan yang mengandung zat besi dan dapat didukung dengan mengkonsumsi tablet penambah darah. Selain anemia, fakor lainnya juga dapat mempengaruhi kejadian bayi BBLR.

\section{Hubungan Status Gizi dengan Kejadian BBLR}

Rosemary (2007) menyatakan bahwa status gizi berdampak pada keadaan gizi ibu dalam mempersiapkan kehamilan. Apabila status gizi ibu buruk, baik sebelum kehamilan dan selama kehamilan akan menyebabkan berat bayi lahir rendah. Kategori status gizi ibu yaitu tidak normal (IMT $<18.5$ atau $>25 \mathrm{~kg} / \mathrm{m}$ ) dan normal. Lingkar lengan atas (LILA) merupakan indikator untuk mengidentifikasi ibu hamil beresiko kurang energi kronis (KEK). Pengukuran menggunakan LILA lebih baik untuk menilai status gizi ibu hamil, karena pada wanita hamil dengan malnutrisi (gizi kurang atau lebih) terkadang menunjukkan oedem dan bagian yang jarang terdapat oedem yaitu bagian lengan atas. Ambang batas LILA dengan resiko KEK di Indonesia adalah $23.5 \mathrm{~cm}$ (Depkes, 2010).

Hasil penelitian menunjukkan bahwa dari 43 responden yang mengalami KEK terdapat 31 responden $(72,1 \%)$ yang mengalami BBLR dan 12 responden $(27,9 \%)$ yang tidak mengalami mengalami BBLR. Selanjutnya dari 45 responden yang tidak mengalami KEK terdapat 13 responden $(28,9 \%)$ yang mengalami BBLR dan 32 responden $(71,1 \%)$ yang tidak mengalami BBLR.

Hasil uji statistik dengan menggunakan uji Chisquare pada $\alpha=5 \%$ dan $\mathrm{df}=1$, diperoleh nilai $p$ value $=0,000$ hal ini berarti hipotesis diterima, artinya bahwa ada hubungan antara status Gizi ibu saat hamil dengan kejadian BBLR di Ruang Bersalin Rumah Sakit Umum Sekota Kendari. Hasil analisis dengan menggunakan uji Odds Ratio diperoleh nilai Odds Ratio $(\mathrm{OR})=6,359$, CI 95\% = 2,516 -16,071, hal ini berarti ibu yang saat hamil mengalami KEK akan berisiko 6,359 kali lebih besar bayinya mengalami BBLR dibandingkan dengan ibu yang saat hamil tidak mengalami KEK. Karena nilai OR $(6,359)>1$, maka status gizi saat hamil merupakan faktor risiko kejadian BBLR di Ruang Bersalin Rumah Sakit Umum Sekota Kendari. Penelitian ini sesuai dengan penelitian yang dilakukan oleh Sri (2009), berdasarkan hasil penelitian diketahui bahwa dari 14 ibu dengan status gizi KEK yang melahirkan BBLR $12(85,7 \%)$ lebih tinggi dibandingkan yang non BBLR $2(14,3 \%)$ dari $27 \mathrm{ibu}$ dengan status gizi non KEK yang melahirkan BBLR 1 (3,7\%) lebih rendah dibandingkan yang non BBLR 26 (96,3\%) hasil analisis disimpulkan bahwa status gizi ibu mempunyai hubungannya yang bermakna secara statistik dengan bayi berat lahir rendah.

Pengukuran lingkar lengan bagian atas (LILA) ibu pada saat hamil sangat penting. Tujuan dilakukan pengukuran LILA untuk mengetahui secara dini status gizi ibu hamil, apabila ukuran LILA $<23,5 \mathrm{~cm}$ maka kemungkinan ibu hamil untuk melahirkan bayi dengan BBLR lebih besar. Sedangkan apabila ukuran LILA > 23,5 cm maka ibu akan melahirkan bayi yang sehat, cukup bulan dengan berat badan normal.Bahwa keadaan gizi pada waktu lahir sangat dipengaruhi oleh keadaan gizi ibu selama hamil. Ibu yang masa hamilnya menderita gangguan gizi selain akan melahirkan bayi dengan berbagai kelainan dalam pertumbuhannya atau mungkin bayi akan lahir mati maupun lahir prematur (belum cukup umur) (Dyah, 2006)

Seorang wanita yang mengalami defisiensi nutrisi sebelum dan selama hamil kemungkinan wanita tersebut akan mengalami KEK selama hamil. KEK adalah keadaan seorang yang kurang gizi yang disebabkan oleh rendahnya konsumsi energi dan protein dalam makanan sehari-hari dan atau gangguan penyakit tertentu (Supariasa et al., 2016). Ibu hamil yang mengalami KEK mempunyai kecenderungan untuk melahirkan bayi dengan BBLR, sedangkan ibu hamil yang memiliki asupan gizi seimbang (Non KEK) cenderung memiliki resiko kecil terhadap BLBR. Kejadian KEK dapat disebabkan oleh asupan energi, dan protein yang tidak seimbang dengan kebutuhan ibu hamil.

\section{KESIMPULAN\& SARAN}

Berdasarkan hasil penelitian yang dilakukan, maka yang menjadi kesimpulan dalam penelitian ini adalah ada hubunganantara anemia dengan kejadian BBLR di Ruang Bersalin Rumah Sakit Umum Sekota Kendari, ada hubungan antara status gizi dengan kejadian BBLR di Ruang Bersalin Rumah Sakit Umum Sekota Kendari

\section{DAFTAR PUSTAKA}

ANIK, M. \& NURHAYATI 2009. Asuhan Kegawatdaruratan dan Penyulit pada Neonatus, Jakarta, Trans Info Media. 
BENDHARI, M. L. \& HARALKAR, S. J. 2015. Study of Maternal Risk Factors for Low Birth Weight Neonates : a Case Control Study. 4, 987990.

DEPKES, R. 2010. Program Safe Motherhood Di Indonesia. Jakarta: Kementrian Kesehatan.

DINKES PROVINSI SULTRA 2018. Laporan Profil Kesehatan Provinsi Sulawesi Tenggara, Kendari, Dinas Kesehatan

KEMENKES RI 2013. Riset Kesehatan Dasar. In: KESEHATAN, D. (ed.). Jakarta.

KEMENKES RI 2015. Profil Kesehatan Indonesia. Jakarta.

PANTIAWATI 2010. Bayi dengan BBLR, Yogyakarta, Nuha Medika.

PROVERAWATI, A. \& ISMAWATI, C. 2010. Berat Badan Lahir Rendah (BBLR), Yogyakarta, Nuha Medika.

SUGIYONO, P. D. 2011. Metode Penelitian Kuantitatif Kualitatif dan $R \& D$, Bandung, Alfabeta.

SUPARIASA, I. D. N., BAKRI, B. \& FAJAR, I. 2016. Penilaian Status Gizi, Jakarta, Penerbit Buku Kedokteran EGC.

UNICEF 2015. Levels and trends in child mortality. New York: Fund UNCs, editor.

WHO 2014. Maternal Mortality. In: ORGANIZATION, W. H. (ed.).

WHO 2015a. Trends in Maternal Mortality: 1990 to 2015, UNICEF, UNFPA, World Bank Group and the United Nations PopulationDivision). Ganeva, Switzerland.

WHO 2015b. World Health Statistics. World Health Organization. 